\title{
A New Osmotolerant Plant Growth Promoting Bacillus Sp1 and Sp2 with Potential Antifungal Activity and Their Utilization of Ulva Lactuca as Natural Osmoprotectant
}

\author{
El hafid Nabti* \\ Laboratoire de Maitrise des Energies Renouvelables, Faculté des Sciences de la Nature et de la Vie, Université de Bejaia, Algeria \\ Submission: October 01, 2018; Published: January 11, 2019 \\ *Corresponding author: El-hafid Nabti, Laboratoire de Maitrise des Energies Renouvelables, Faculté des Sciences de la Nature et de la Vie, \\ Université de Bejaia, 06000 Bejaia, Algeria
}

\begin{abstract}
Two bacterial strains (Bacillus Sp.1 and Sp.2) were isolated from the rhizospheric agricultural soil (West of Bejaia- Algeria). The two strains are identified using phenotypic analyses (API system 50CHB/E) and 16SrDNA-bvased phylogeny. These strains are halotolerant (300 and 400 $\mathrm{moml} / \mathrm{L} \mathrm{NaCl}$ ), respectively. They used glycine betaine, proline and marine algal extracts of Ulva lactuca as osmoprotectants. The two strains produce high amount of auxin-phytohormone (IAA: 98.60-119.00 mg /L); different enzymes; siderophores; solubilize phosphorus. They show an interesting antifungal activity against various phytopathogens.
\end{abstract}

Among PGPR, the genus Bacillus is known to have more characters promoting plant growth:

(i) Ability to synthesize phytohormones such as IAA,

(ii)

(iii) Antifungal activities by siderophores production; antibiotics and several enzymes, and

(iv) Phosphorus solubilization. It also appears as a potential candidate to be a good biofertilizer through its ability to sporulate. So, it resists toward severe conditions (water and salt stress).

Keywords: PGPR, Bacillus; Stress-osmoprotective substances; Antifungal-activity

Abbrevations: UL: Ulva Lactuca; GB: Glycine Betaine; VD: Verticillium Dahliae; FO: Fusarium oxysporum; BF: Botryotinia Fuckiliana; PC: Phytophthora Cinamomi; PCA: Phytophthora Cactorum; CA: Colletotrichum Acutatum; BC: Botrytis cinereal; AN: Aspergillus Niger; AF: Aspergillus flavus

\section{Introduction}

More than 30 million hectares of agricultural soils becomes inusable. These soils are degraded and destroyed by many factors such: salinity, temperature, organic matter loss and erosion [1]. Many arid and semi-arid zones are exclusively threated by salnity and salinization. The two factors affecting and inhibiting plant growth and development, which leads to decrease the crops yield $[2,3]$.

Another menace, based on pathogenic fungi, which affects severely food production and the ecosystems stability. Bacillus is well know as a potential genus gathering many strains of plant growth promoting rhizobacteria PGPR)) stimulating plant growth under normal and stressful conditions. These bacteria are in plant health protection and induction of resistance against phytopathogenic organisms. PGPB can affect plant metabolism via nitrogen fixation, mineral solubilization, plant hormones modulation and plant tolerance improvement to abiotic stresses (drought, salinity, nutrient deficiency etc.) [4].

\section{Materiel and Methods}

Soil samples were taken from the rhizosphere of potato (Bejaia, Algeria). They are randomly chosen in greenhouse in the East of Bejaia (Algeria) in front to the sea. The soil contained the following composition: salinity 1.14\%, pH 6.9, N $69 \mu \mathrm{g} \mathrm{g-1,} \mathrm{P} 3 \mu \mathrm{g}$ g-1, K $6 \mu \mathrm{g}$ g-1 and water capacity $28 \%$. Samples were prepared according to [5]. After appropriate dilutions, samples were inoculated on the following agar medium $\left(30 \mathrm{mmol} / \mathrm{L}\right.$ succinate, $10 \mathrm{mmol} / \mathrm{L} \mathrm{NH}_{4} \mathrm{Cl}$, $14 \mathrm{~g} \mathrm{~K}_{2} \mathrm{HPO}_{4}$, $2.7 \mathrm{~g} \mathrm{KH}_{2} \mathrm{PO}_{4}, 2.5 \mathrm{M} \mathrm{NaCl}, 5 \mathrm{ml} 2 \% \mathrm{MgSO}_{4}$ solution, 4 
$\mathrm{mmol} / \mathrm{L} \mathrm{FeSO} 4$ and $50 \mu \mathrm{L}$ fungicide, $\mathrm{pH}$ 7.2). Plates were incubated for 7 days at $30^{\circ} \mathrm{C}$. In parallel, in order to screen bacteria on the base of their osmotolerance, the same medium was performed but with different $\mathrm{NaCl}$-concentrations from 1.72 to $1000 \mathrm{mmol} / \mathrm{L}$ $\mathrm{NaCl}$. After incubation at $30 \mathrm{C}$ for 7 days, the number of bacteria in the soil sample was calculated by counting colonies forming in the defined agar plates. Only 10 colonies were obtained on plates with $0.5 \mathrm{M} \mathrm{NaCl}$, while no growth was observed up then $0.5 \mathrm{M} \mathrm{NaCl}$. The screen was continued on the same agar medium (1.72-1000 $\mathrm{mmol} / \mathrm{L} \mathrm{NaCl}$ ) containing proline (Pro), Glycine Betaine (GB) and Ulva Lactuca (UL) extracts with respective final concentrations of $1 \mathrm{mmol} / \mathrm{L}, 1 \mathrm{mmol} / \mathrm{L}$ and $10 \%$ Two bacterial strains only showed the best growth at $1 \mathrm{M} \mathrm{NaCl}$ in presence of (UL) [6]. One strain is grown in presence of (Pro) at $700 \mathrm{mmol} / \mathrm{L} \mathrm{NaCl}$, and the other one is grown in $800 \mathrm{mmol} / \mathrm{L} \mathrm{NaCl}$ when (GB) is added. The two strains were finally chosen to be identified.

Identification based on Gram staining, mobility was performed. For other biochemical characters, the API system 50CHB/E was performed (bio-Merieux, Marcy l'Etoile, France). 16S rDNABased Strain characterization was conducted after total DNA isolation. 16SrDNA partial sequences $(1500 \mathrm{bp})$ were compared to databases using BLASTN 2.2.24. Sequences alignment and phylogenetic reconstruction were inferred using Clustalw 0.82 Software and Phylip3.6bPackage, respectively $[7,8]$. Plant growth promoting characters were studied: IAA production, phosphorus solubilization [9,10], siderophores. Different enzymes were searched: chitinase, cellulase, amylase, protease, urease and lipase. These two strains are also tested for their antagonistic activity against various phytopathogenic fungi [11-18]. Verticillium Dahliae (Vd), Fusarium oxysporum (Fo); Botryotinia fuckiliana (Bf) Phytophthora cinamomi (Pc), Phytophthora cactorum (Pca) Colletotrichum acutatum (Ca): Botrytis cinerea (Bc) Aspergillus Niger (An) and Aspergillus flavus (Af).

\section{Results and discussion}

Gram staining of the three strains showed two strains are Gram positive (named E23 and E32). Bacillus sp1 showed 74\% of similarity with B. amyloliquefciens [18], and $68 \%$ with $B$. licheniformis [19]. While Bacillus Sp2 has similarities of $62 \%$ and $60 \%$ with B. amyloliquefciens and B. licheniformis, respectively $[18,19]$. The 16SrDNA partial sequence placed the isolate E23 within the Bacillus licheniformis cluster with 98\% 16SrDNA of similarity to the strains B. licheniformis DQ082997.1 and Bacillus licheniformis MMOL/LL2501 (gene Bank). Bacillus Sp.2 is located in another cluster. Thus, the strain is a Bacillus $S p$. with similarities of $99 \%$ to Bacillus Sp. R-(ABO21181.1) and Bacillus Sp. R-30632 (data not shown).

Bacillus Sp1 and Sp2 have the respective optimal growth of $400 \mathrm{mmol} / \mathrm{L}$ and $300 \mathrm{mmol} / \mathrm{L} \mathrm{NaCl}$, in absence of osmoprotectants (Figure 1). So, these strains is considered as halophilic bacterium. In other hand, growth of both strains increased significantly in the presence of (GB), (PR) and (UL) values reached $800 \mathrm{mmol} / \mathrm{L}$ (Sp1) and $500 \mathrm{mmol} / \mathrm{L}$ (Sp2) (+ GB), $500 \mathrm{mmol} / \mathrm{L}$ (Sp.1) $700 \mathrm{mmol} / \mathrm{L}$ $\mathrm{NaCl}$ (Sp2) (+ PR) and $1000 \mathrm{mmol} / \mathrm{L} \mathrm{NaCl}$ for both of strains, respectively. In this case, we highlight the best growth of the two strains when the marine algal extracts were putted. Statistical analysis (ANOVA) using Fischer's test (LSD) at interval of 95\% $(\mathrm{p} \leq 0.05$ ) supported our results (Figure 2). Bacteria usually use amine-containing compounds such as proline, glycine betaine as osmoprotectants [20].

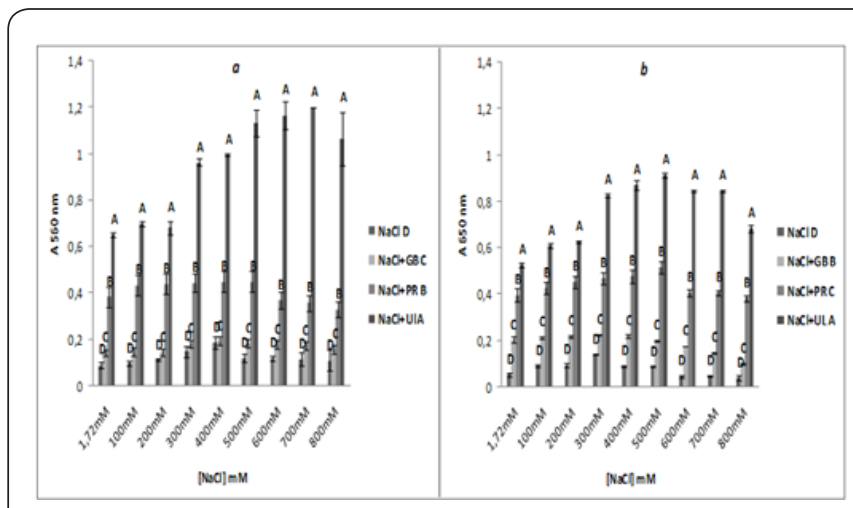

Figure 1: Comparison of the both strains growth under saline conditions and their ability to use the osmoprotective substances.

The letters (A, B, C and D) denote the homogeneous groups obtained by the Fischer LSD test ( $p \leq 0.05)$. a: Bacillus Sp1; b: Bacillus Sp2

A large amount of GB is accumulated by Bacillus subtilis from the external environment in high saltiness, using three transport control systems [21,22]. Proline is a potential osmoprotectant in various halophilic Bacillus and non-halophilic species as Bacillus subtilis [23]. Halobacillus halophilus accumulates proline in response to high salinity ( $>2 \mathrm{M} \mathrm{NaCl}$ ) [24]. Proline may be uptake by Bacillus subtilis from the medium using a specific transport system (Opu E) [25].

Table 1: Different characters of Bacillus Sp1 and Sp2.

\begin{tabular}{|c|c|c|c|c|c|c|c|c|c|}
\hline $\begin{array}{c}\text { Charac- } \\
\text { ters }\end{array}$ & $\begin{array}{c}\text { IAA } \\
\text { (mg/L) }\end{array}$ & Cel & Chit & Prot & Lip & Amy & Ure & Phos & Sid \\
\hline $\begin{array}{c}\text { Bacillus } \\
\text { Sp1 }\end{array}$ & 98.6 & +++ & +++ & +++ & +++ & +++ & +++ & NBRIP + \\
\hline $\begin{array}{c}\text { Bacillus } \\
\text { Sp2 }\end{array}$ & 119 & +++ & +++ & +++ & +++ & +++ & +++ & NBRIP + \\
\hline
\end{tabular}

+ corresponds to the positive activity; +++ means strong positive activity.

Cel: cellulase, Chit: Chitinase, Prot: Protease, Lip: Lipase, Amy: Amylase, Ure: urease, Pho: Phosphatase, Sider: Siderophore.

Additionally, it is very clear that the presence of algal extracts under salinity. Therefore, growth achieved the best value $(>1000$ enhanced and improved broadly the growth of the two strains $\mathrm{mmol} / \mathrm{L} \mathrm{NaCl}$ ). The positive effect of (UL) as osmoprotectant 
has been already demonstrated [5]. The study of the benefic characters of Bacillus the strains are illustrated in Table I.

Both of strains Sp1 and Sp2 had an important character for soil fertilization (cellulase, chitinase, protease, lipase, amylase and urease), phosphorus solubilization, IAA-production $98.60 \mathrm{mg} / \mathrm{L}$ (Sp1) and $119.00 \mathrm{mg} / \mathrm{L}$ (Sp2). The two strains could help plant growth by siderophores production and a probable N2 fixation [26]. Many strains of Bacillus with agricultural characters were isolated from soybean rhizosphere (Glycine max L.). These strains produced IAA (0.81 to $86.82 \mathrm{mg} / \mathrm{L}$ ), thus, they enhanced seeds germination and growth of soybean [27]. Our strains produce a very high IAA quantity (98.60-119.00 mg/L). The two Bacillus isolates $S p 1$ and $S p 2$ solubilize tricalcium phosphate in vitro. This character is important for an eventual application in agriculture. Pseudomonas $S p$ and Bacillus $S p$ increased the availability of phosphorus in soil; as a result, they are used as biofertilizer in alkaline soils [28].

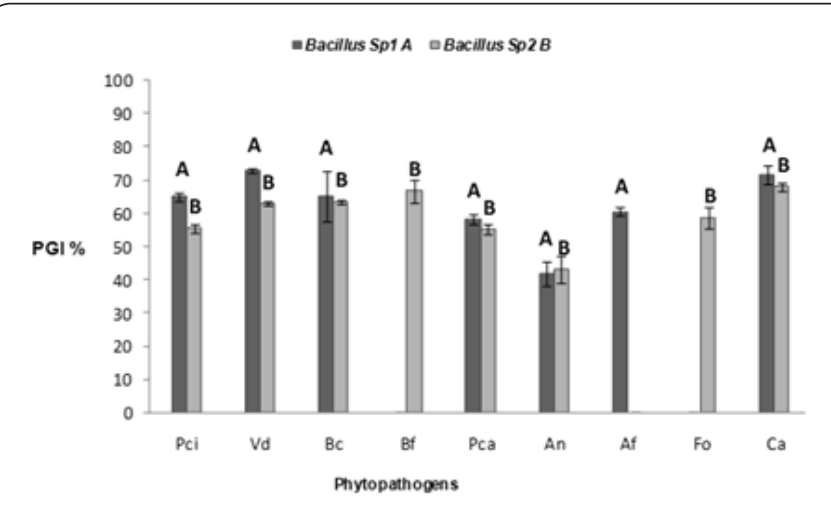

Figure 2: (PGI \%) plant pathogenic fungi by the tow Bacillus strains

The letters $(A, B)$ : homogeneous groups obtained by the Fischer LSD test $(p \leq 0.05)$.

Vd: Verticillium dahliae; for: Fusarium oxysporum; Bf: Botryotinia fuckiliana; Pc: Phytophthora cinamomi; Pca: Phytophthora cactorum, Ca: Colletotrichum acutatum, and Bc: Botrytis cinerea, An: Aspergillus Niger, Af: Aspergillus flavus.

Bacillus strains Sp1 and Sp2 are tested against nine phytopathogenic fungi how cause significant losses in agriculture and reduce crops and are often targeted in biological control [29]. The two Bacillus strains show a good inhibition of mycelial growth $(>60 \%$ ) of the majority of targets (Figure 2). Several mechanisms have been proposed to explain the inhibition of phytopathogenic fungi by Bacillus $s p$, including antibiotic production, hydrolytic enzymes secretion, competition for nutrients, or a combination of these mechanisms in synergy [30]. The production of siderophores is a major mechanism of biological control found in many groups of PGPR, including Bacillus sp., which produces a large variety of siderophores involved in iron chelating, therefore, the availability of this component in environment will be decreased and beers to eliminate the pathogenic fungi [31].

Bacillus strains SP1 and SP2 have a variable antagonistic activity on plant pathogenic fungi with PGI\% target variables are shown in Figure 2. In addition to siderophores, some microorganisms synthesize chitinases, $\beta$-1,3-glucanases or cellulases. These enzymes damage fungal cell wall components leading to cell lysis [32]. Some studies revealed a correlation between the chitinolytic activity of Bacillus Sp, Pseudomonas Sp, Streptomyces Sp and their ability to inhibit Fusarium oxysporum and Fusarium solani mycelial growth [33]. It shown that cellulase is also involved in the abolishment of Phytophthora cactorum growth by removing the oospores from the mycelium [30]. However, different mechanisms can be gathered in synergy, including production antibiotics and volatile compounds $[34,35]$. Our study showed that the two Bacillus strains Sp1 and Sp2 produce siderophores and many enzymes with biocontrol activities (cellulase, chitinase, protease, and lipase).

Finally, two Bacillus strains could be qualified as halotolerant PGPR, utilize glycine betaine; proline and algal extracts as osmoprotectants. The capacity of these strains to produce high IAA quantity should be important to stimulate the plants growth. Other than, phosphorus solubilization and enzymes production are benefic to fertilize the soils.

\section{Conclusion}

Both of strains could be considered as candidates for further application as biofertilizers and bio- stimulants as well as biocontrol agents.

\section{References}

1. Itier B (2008) Agriculture et recherche: le contexte et les enjeux. Innovation Agronomique 2: 1-8.

2. Borges AA, Jiménez-Arias D, Expósito-Rodríguez M, Sandalio LM, Pérez JA (2014) Priming crops against biotic and abiotic stresses: MSB as a tool for studying mechanisms. Front Plant Sci 5: 642.

3. Bensidhoum L, Nabti El-H, Tabli N, Kupferschmied P, Weiss A, et al. (2016) Heavy metal tolerant Pseudomonas protegens agricultural well water in northeastern Algeria with plant growth promoting, insecticidal and antifungal activities. European Journal of Soil Biology 75: 38-46.

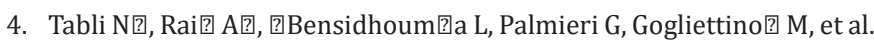
(2018) Plant growth promoting and inducible antifungal activities of irrigation well water-bacteria. Biological Control 117: 78-86.

5. Çelen E, Mehmet AK (2004) Isolation and characterization of aerobic denitrifiers from agriculture soil, Turk J Biol. 28: 9-14.

6. Nabti E, Sahnoune M, Adjrad S, Van Dommolen A, Ghoul M, et al. (2007) A halophilic Azospirillum brasilense strain and osmotolerant from Algerian soil wheat growth restores Under saline conditions. Eng Life Sci 7(4) 354-360.

7. Thompson JD, Higgins DG, Gibson TJ (1994) Improving the sensitivity of progressive multiple sequence alignment through sequence weighting, position-specific gap penalties and weight matrix choice. Nucleic Acids Res 22(22): 4673-4680.

8. Felsenstein J, Phylip (2000) Phylogeny Inference Package, Version 3.6b (beta release), Department of Genome Sciences University of Washington. Washington (USA).

9. Patten CL, Glick BR (2002) Role of Pseudomonas putida indole acetic acid in development of the host plant root system. Appl Approx Microbiol 68(8): 3795-3801. 
10. Nautiyal CS (1999) An efficient Microbiological growth medium for screening phosphate solubilizing microorganisms. FEMS Microbiol Lett 170(1): 265-270.

11. Schwyn B, Neilands JB (1986) Universal Chemical Assay for the Detection and Determination of siderophores. Anal Biochem 160(1): 47-56.

12. Kopečný J, Hodrová B, Stewart CS (1996) The isolation and characterization of a rumen chitinolytic bacterium. Lett Appl Microbiol 23(3): 195-198.

13. Carder JH (1986) Detection and quantification of cellulase by Congo red staining of sunstrates in a cup-plate difussion assay. Anal Biochem 153(1): 75-79.

14. Bach HJ, Munch JC (2000) Identification of bacterial sources of soil peptidases. Biol Fertil Soils 31(3-4): 219-224.

15. Christensen WB (1946) Urea Decomposition as a Means of Differentiating Proteus and Paracolon Cultures from Each Other and from Salmonella and Shigella Types. Journal of Bacteriology 52(4): 461-466.

16. Anderson JA (1939) The use of tributyrin agar in dairy bacteriology.

17. Živković S, Stojanović S, Ivanović Ž, avrilović GV, T Popović J, et al. (2010) Screening of antagonistic activity of microorganisms Against Colletotrichum acutatum and Colletotrichum gloeosporioides. Arch Biol Sci Belgrade 62 (3): 611-623.

18. Logan NA, Berkeley RCW (1984) Identification of Bacillus Strains Using the API System. J Gen Microbiol 130(7): 1871-1 882.

19. Gibson T (1944) A study of Bacillus subtilis and related organisms. Journal of Dairy Research 13(3): 248-260.

20. Zahran HH (1997) Diversity, adaptation and activity of the bacterial flora in saline environments. Biology and Fertility of Soils 25(3): 211223.

21. Poolman B, E Glaasker (1998) Regulation of compatible solute accumulation in bacteria. Mol Microbiol 29 (2): 397-407.

22. Boch J, Kempf B, Bremer E (1994) Osmoregulation in Bacillus subtilis: Synthesis of the osmoprotectant glycine betaine from choline Exogenously Provided choline. J Bacteriol 176(17): 5364-5371.

23. Empadinhas N, da Costa MS (2008) Osmoadaptation Mechanisms in prokaryotes: Distribution of compatible solutes. Int Microbiol 11(3): 151-161.
24.Saum SH, Müller V (2008) Regulation of osmoadaptation in the moderate halophile Halobacillus halophilus: chloride, glutamate and switching osmolyte strategies. Saline Systems 4:4.

25. Kempf B, Bremer E (1998) Uptake and synthesis of compatible microbial stress responses Solutions as to high-osmolarity environments. Arch Microbiol170(5): 319-330.

26. Döbereiner J, Marrielle IE, Nery M (1976) Ecological distribution of Spirillum lipoferum Beijerink. Can J Microbiol 22(10): 1464-1473.

27. Wahyudi AT, Rina AP, Widyawati A, Meryandini A, Nawangsih AA (2011) Characterization of Bacillus $s p$. strains isolated from rhizosphere of soybean plants for use as Their Potential for Promoting Rhizobacteria plant growth. Journal of Microbiology and Antimicrobials 3 (2): 34-40.

28. Rodriguez H, Fraga R (1999) Phosphate solubilizing bacteria and Their role in plant growth promotion. Biotechnol Adv 17(4-5): 319-339.

29. Soylu S, Soylu EM, Kurt S, Ekici OK (2005) Antagonistic potentials of rhizosphere bacterial isolates associated against soil-borne diseases of tomato and pepper Caused by Sclerotinia sclerotiorum and Rhizoctonia solani. Pakistan Journal of Biological Sciences 8(1): 43-48.

30. Calvo P, Ormeño Orrillo E, Martínez Romero E, Zúñiga D (2010) characterization of isolates of Bacillus from potato rhizosphere soils of andean peru Characteristics and Their Potential PGPR characteristics. Brazilian Journal of Microbiology 41(4): 899-9060.

31. Compass S, Duffy B, Nowak J, Ait Barka E, Clement T (2005) Use of Plant Growth-Promoting Bacteria for Biocontrol of Plant Diseases: Principles, Mecahanisms of Action, and Future prospects. Appl Environ Microbiol 71(9): 4951-4959.

32. Whipps JM (2001) Microbial interactions and biocontrol in the rhizosphere. J Experiment Bot 52(1): 487-511.

33. Lim H, Kim S, Kim YSD (1991) Pseudomonas stutzeri YPL-1 genetic transformation and antifungal Mechanism Against Fusarium solani, an agent of plant root rot. Appl Environ Microbiol 57(2): 510-516.

34. El Hamshary IOM, Abo-Aba SEM, Awad N, Gomaa AM (2008) Genetic Profile of Bacillus cereus and Bacillus subtilis Indigenous Isolates and Their Performance as Bio-Control Agent Against the Plant Pathogen Fusarium oxysporum. Research Journal of Cell and Molecular Biology 2 (2): $30-38$.

35. Keen T, Vancover B (2010) Phytophthora cinnamomi suppressive soils. Current Research, Technology and Education Topics in Applied Microbiology and Biotechnology Microbiol. A Mendez-Vilas (Ed.) 239250 .

\section{Your next submission with Juniper Publishers will reach you the below assets}

- Quality Editorial service

- Swift Peer Review

- Reprints availability

- E-prints Service

- Manuscript Podcast for convenient understanding

- Global attainment for your research

- Manuscript accessibility in different formats

( Pdf, E-pub, Full Text, Audio)

- Unceasing customer service

Track the below URL for one-step submission https://juniperpublishers.com/online-submission.php 